The Promised Territories: The Production of Branded Housing Projects in Contemporary Turkey

Bilge Serin

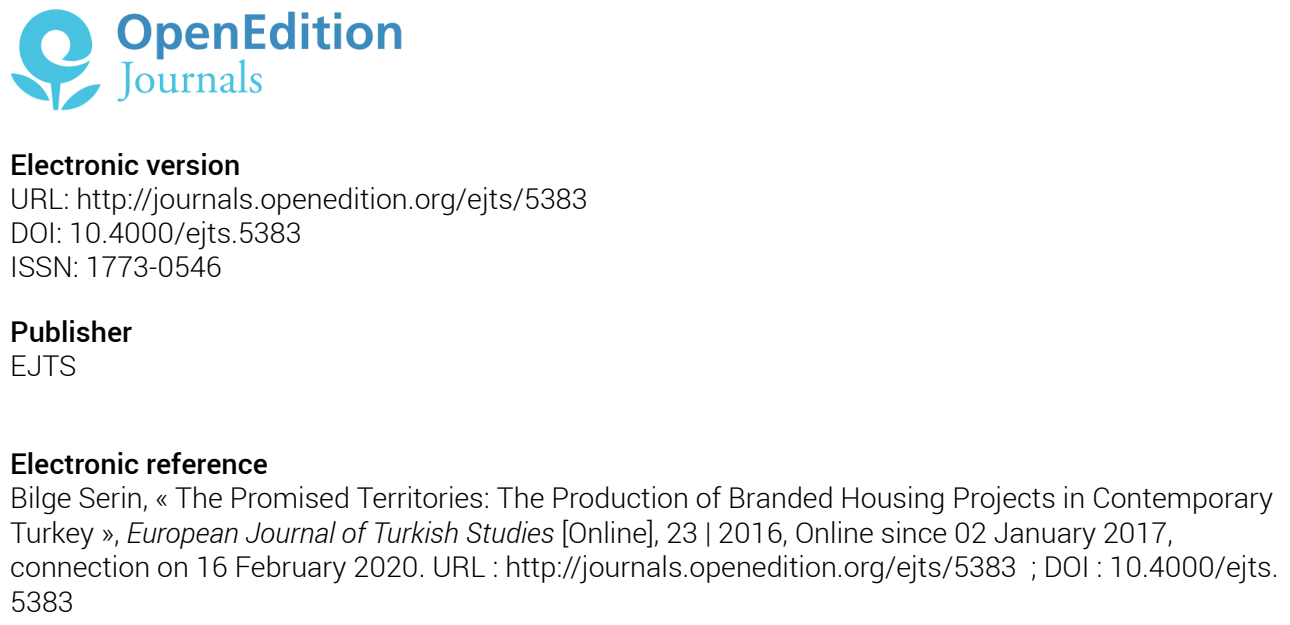

This text was automatically generated on 16 February 2020.

(c) Some rights reserved / Creative Commons license 


\title{
The Promised Territories: The Production of Branded Housing Projects in Contemporary Turkey
}

\author{
Bilge Serin
}

\section{Introduction}

1 Neoliberal restructuring processes have been taking place since the early 1970 s as a global phenomenon (Harvey 2007; Peck et al. 2009; Brenner and Theodore 2002). Through neoliberalization, states started to dismantle the post-war institutional structure (crisis in Keynesian economics and the welfare state) and implement policies of marketization, commodification and fostering competition (Peck et al. 2009: 50). Through global transformations in the world capitalist system, neoliberalism became the "dominant political and ideological form of capitalist globalization" (Ibid.).

2 As part of neoliberal restructuring, neoliberal urbanization processes have been observable in the practice of the production of space. Peck et al. (2013: 1093) argue that cities are not passive recipients, but neoliberalization processes are continuously and actively constituted through global urbanizing regions. Therefore, since the 1990s, urban areas have become critical places for understanding the dynamics, such as the limits, contradictions or changes, of neoliberalism (Peck et al. 2009: 49).

3 Through the rise of neoliberal urbanization, housing enclaves have become a way of urban space production in many countries and with different versions. Blakely and Snyder (1997: 2) define housing enclaves as gated communities, i.e. as "residential areas with restricted access in which normally public space are privatised". Borsdorf and Hidalgo (2010) point out the widespread development of, and boom in, gated communities [barrios cerrados] in Latin American countries, - which are described as "a dwelling complex that contains more than one unit, has a common infrastructure, and is separated from the public by gates and fences or walls" (Borsdorf and Hidalgo 2010: 26-27) and with urban infrastructure and social facilities. Other versions of housing 
enclaves include the condominium estates in Singapore (Pow 2009) and the residential parks in Hungary defined by Bodnar and Molnar (2010). Bagageen (2010: 15) argues that housing enclaves are popular in the Middle East and gated living "is being advertised as offering the very best of city living, which is about connecting with family, friends, and a 'life you've always dreamed about', offering urban life with all the amenities of a metropolitan centre and the added comfort of the security of an exclusive community". As part of this global expansion, branded housing projects have developed in Turkey as a version of housing enclaves since the early 2000 s following the deepening of neoliberal restructuring processes in the country.

\section{Neoliberal Urbanization in Turkey}

4 Following the 1970s global oil crisis, transformations and radical changes in the economy, politics, and culture of Turkey were being "felt in almost every sphere of life" (Keyman and Gümüşçü 2014: 22). Turkey's integration into the global market started in the 1980s and has continued into the post-2001 period (Güngen 2006: 332). Balaban argues that the post-1980 period marks a breaking point in terms of accumulation of capital and distribution policies. In this period, while neoliberal restructuring policies were implemented in order to integrate Turkey's economy into the global economy, radical attempts were made to make the production of the built environment instrumental in terms of neoliberal policies (Balaban 2013: 57) As a result of the implementation of neo-liberal urban policies, political instability and crises, socioeconomic polarisation, and spatial inequalities have deepened and produced chronic urban poverty (Bayırbağ 2010: 292).

5 The second half of the neoliberal restructuring process started with the 1998 and 1999 IMF agreements (Ataay 2006: 18), and was formulated as a structural adjustment programme called the Programme of Transition to a Powerful Economy [Türkiye'nin Güçlü Ekonomiye Geçiş Programl] in 2001 (Balaban 2013: 59). While applying this programme, Turkey experienced "the worst financial crisis in its history" (Demirtaş 2012: 213). Kuyucu and Ünsal (2010: 1484) define the 2001 crash as a "major accumulation crisis" and a breaking point for establishing a "fully neo-liberal system". However, despite the economic crisis, in the post-2001 period successive governments (formed in 2002, 2007, and 2011) have continued to follow the same path (Özdemir 2012) and implemented neoliberal policies which "have been realised in accordance with the directives coming from the IMF and the World Bank" (Zabc1 2012: 252). The Urgent Action Plan [Acil Eylem Plani] was implemented in 2002 as part of this restructuring process (Ataay 2006: 18). The implementation of structural reforms was subsequently accelerated and extensively implemented until the 2011 government (Zabc1 2012: 254-255). The decrease in pace after 2011 was due to the near completion of the reform process, and not as a result of a policy change (Ibid.).

This transformation of the state or political society presents an example of neoliberal state formation. Harvey (2007: 7) defines the neoliberal state as "a state apparatus whose fundamental mission was to facilitate conditions for profitable capital accumulation on the part of both domestic and foreign capital". According to Harvey (2005: 32), the state plays a crucial role in promoting and backing up the processes of neoliberalization with its role of legality and monopoly of violence. In addition, Aalbers (2013a: 1054) emphasises the role of the state in the "forced introduction of market 
models and regulation in most sections of life". According to Aalbers (Ibid.), "[a]ctually existing neoliberalism was never really devoted to creating free markets". Despite the theory (and discourse) of neoliberalism claiming the contrary, states are "not external but central to neoliberalism" (Aalbers 2013b: 1084), and "state intervention under neoliberalism has actually been severe" (Aalbers 2013a: 1054).

7 Cities in Turkey follow the neoliberal restructuring of the country as critical places for this restructuring. Following the 2001 economic crash, the governance of real estate markets was radically restructured (Kuyucu and Ünsal 2010: 1484) alongside governance, planning, and urban development legislation in order to enable and speedup investment in construction, real estate, and tourism (Balaban 2013: 64). Balaban (2012) defines the post-2001 construction boom as an increase in the volume of construction activity in Turkey resulting from the unprecedented rise of the construction sector's share of the GDP and employment, and financial and capital investments that occurred between 2001 and 2007. In the post-2001 period, investment in the housing sector also increased, and capital moved into the housing sector from other sectors such as tourism or textiles (Pérouse 2013: 82).

8 As part of this construction boom, branded housing projects have emerged in the last fifteen years. These projects produce territories in the form of housing enclaves, which provide key services and facilities within their confines exclusively for project residents. However, urbanisation in Turkey has already had a prior experience of housing enclaves. Although initiated in the 1980s, the development of housing enclaves in Istanbul expanded in the 1990s (Kurtuluş 2005: 165), and continued into the 2000s (Candan and Kolluoğlu 2008: 5) as part of the wider neoliberal restructuring process being carried out in Turkey (Altun 2012: 41). Geniş (2007: 773) emphasises the development of these enclaves in the first place and their subsequent expansion as being facilitated by neoliberal policies in Turkey. As part of this wider development pattern, by 2013 the total number of branded housing projects in İstanbul had reached 852 with the number of units provided by these projects amounting to $7.7 \%$ of the total housing stock in the city (Sarıçayır 01/21/2014).

9 The article discusses the role of political society and civil society in the production of branded housing projects as contemporary territories in Turkey by focusing on the case of the branded housing projects produced by Emlak Konut GYO (Real Estate Partnership) in Istanbul between 2003 and 2014. Firstly, the role of political society is discussed through the role of TOKI [Toplu Konut İdaresi / Housing Development Administration of Turkey] and Emlak Konut GYO as major public actors in the development of these territories; and secondly, the role of civil society is discussed through excavating the traces of production of social consent for branded housing projects in the news articles published on Emlak Konut GYO projects between 2003 and 2014. Branded housing projects located in Istanbul have been selected as the case due to their pioneering role in the production of branded housing in Turkey. Istanbul accommodates the very first branded housing projects developed by Emlak Konut GYO in partnership with private developers. The expansion of branded housing projects in Istanbul has been followed by successive branded developments in Izmir and Ankara, and later in smaller scale cities, although these do not fall within the scope of this paper. 


\section{A Gramscian-Lefebvrian approach to the production of territories}

10 Sidgwick (1891 quoted in Moore 2015: v) says that "[i]n modern political thought, the connection between a political society and its territory is so close that the two notions almost blend". Discussions of territories and the dynamics of the production of territories present an extensive literature. Cox (2002) defines territory and territoriality as the core concepts of political geography. While international relations literature is mostly based on states as territories, as Delaney (2008: 4-5) argues, "[t]here are innumerable complex territorial configurations and assemblages that shape human social life, relationships, and interactions". Therefore, the dynamics of the production of territories are not limited to sovereignty or authority over space or through space. Rather, in urban space and personal space, territories and the production dynamics of territories present more complex configurations and assemblages. For example, Lofland (1998: 9) argues that the public realm is "the city's quintessential social territory", while Hansson (2007: 9) defines the private sphere as "an emotional territory". From this perspective, the dynamics of the production of territories are directly related to the dynamics of the production of space, while adding a layer of boundaries on the production and embodiment of these dynamics through the territories (for both abstract and tangible ones). That is to say, territories (such as personal, abstract, and social ones) are the embodiments of the dynamics of the production of space; and, branded housing projects as territories are products of the intricate relationships of the dynamics of the production of urban space.

11 As Mosco (2009: 156) asserts for communication, neither the dynamics of political society nor those of civil society contain "the only key to unlock our understanding" of the production of branded housing projects as emerging spatial territories in contemporary Turkey. There is a dialectical relationship between the two 'levels'. However, since branded housing is a spatial phenomenon, in order to explain the formation of branded housing projects as territories, the discussion should be expanded to include the production of space as well. This relational expansion allows a theoretical discussion of the emergence of branded housing projects as territories by combining the aspects of political society and civil society together with the aspects of urban space.

12 Kipfer (2002: 119) puts forward a possible theoretical opening for developing such an approach: "excavating an urban Marxism through Gramsci and Lefebvre may help develop an understanding of the reorganization of capitalism by extending recent middle-range analyses of 'urban hegemony' from state theory and urban political economy to everyday life". According to Kipfer, Lefebvre's and Gramsci's approaches to hegemony are "different but complementary" (Kipfer 2002: 126). While Gramsci's approach focuses on "particular historic-geographical constellations of state and civil society", Lefebvre's approach focuses on the "universalizing ... tendencies of commodification and moments of utopian possibility manifested within the contradictions of everyday life" (Ibid.).

On the other hand, for both Gramsci and Lefebvre, hegemony is "the contingent process through which capitalist totality is constructed" (Ibid.), which itself is constructed through the "links between popular culture and 'relations of force' among socio-political forces (Gramsci) and the connections between everyday life, the state, capital, and dominant knowledge (Lefebvre)" (Ibid.: 126-127). Both authors focus on 
cultural phenomena, common sense, and everyday life, and both accept power as a social relationship without reducing social relations "to disciplinary effects of microtechnologies of knowledge / power" (Ibid.: 127).

\section{Political Society and Civil Society in Production of Branded Housing Projects as Territories}

Branded housing projects as emerging territories are co-products of political society and civil society (in Gramscian terms): political society regulates and directly contributes to the production of these territories through public actors involved in branded housing projects (e.g. TOKI and Emlak Konut GYO); and civil society contributes through the production of social consent for such developments via mass media (e.g. news articles about the projects, advertisements for the projects).

Gramsci made a methodological differentiation between political society and civil society.

...the one that can be called "civil society", that is the ensemble of organisms commonly called "private", and that of "political society" or the state. These two levels correspond on the one hand to the function of "hegemony" which the dominant group exercises throughout society and on the other hand to that of "direct domination" or commands exercised through state and "juridical" government. (Gramsci 2000: 306)

In this sense, civil society is "the sum of social activities and institutions which are not directly part of the government, the judiciary of the representative bodies (police, armed forces)" (Forgacs 2000: 420), while political society corresponds to "a sphere of 'domination', the organ or instrument of the oppression of one class by another" (Ibid: 429). The two, civil society and political society, are nested within each other. As Thomas (2011: 180-181) explains, "Gramsci's civil society has a dialectical, nonexclusionary and functional relationship to that other major superstructural 'level', or form, of 'political society or State"'.

17 Power is based on gaining the consent of people and the capacity to build consent production processes. According to Jones, "Gramsci's highly original understanding of power sees it as something actively lived by the oppressed as a form of common sense" (Jones 2006: 4). Gramsci's theory of hegemony, as Jones (2006) states, is different from domination. According to Mosco (2009), Gramsci "sought to understand the specific contours of advanced capitalist societies by concentrating on their capacity to base control on consent more than on physical coercion" (Mosco 2009: 206). Hegemony describes "how our common-sense view of society is constituted" (Ibid.). Gramsci argues that common sense is "the conception of the world which is uncritically absorbed by the various social and cultural environments in which the moral individuality of average man is developed" (in Harvey 2005: 64). In this respect, building 'common sense' is an important part of building hegemony.

From this perspective, without a certain level of social consent for the production of urban spaces by branded housing projects, the expansion of these housing projects would be unlikely. Therefore, investigating the hegemonic expansion of branded housing projects requires an investigation of the dynamics of political society and civil society, including common sense and consent. 


\section{The Production of Space and of Branded Housing Projects as Territories}

19 dynamics of the production of urban space. Lefebvre conceptualizes the urban as a form and mediation (Kipfer 2002: 138). Therefore, urban space is a social product, which Lefebvre (1992: 33) explains through his conceptual triad: spatial practice, spaces of representation and representational space. Spatial practice is the "physical form, real space, space that is generated and used" (Elden 2004: 190); the representation of space is "state-bound interventions of policy, planning and dominant knowledge" (Kipfer 2002: 138); and representational space embodies "complex symbolisms, sometimes coded, sometimes not, linked to the clandestine or underground side of social life" (Lefebvre 1992: 33).

Lefebvre places emphasis on the unity of space, thus these three moments are not separate. It is a unity of "the forces of production and their component elements (nature, labour, technology, knowledge); structures (property relations); superstructures (institutions and the state itself)" (Lefebvre 1992: 85). The concept of social space "sets a very specific dialectic in motion, which, while it does not abolish the production-consumption relationship as this applies to things (goods, commodities, objects of exchange), certainly does modify it by widening it" (Ibid.).

Regarding the role of civil society and political society in the production of territories, revisiting the Lefebvrian framework provides some insights to spatialize these aspects. Firstly, considering political society together with Lefebvre's representations of space, allows for the consideration of the regulation of the material production of territories. In this sense, political society as a regulating force and judiciary body is the major actor in the production of representations of space. Political society dominates and controls the representations of space and, therefore, takes control over at least some aspects of the production of urban space. Secondly, considering civil society, common sense and the production of consent together with Lefebvre's representational space, allows the consideration of the discursive formation of territories. In this sense, the production of common sense and social consent becomes a struggle over representational space, a war for the appropriation of representational space. Therefore, since representational space is one part of the triad of the production of space, the appropriation of it becomes the appropriation of space itself.

The research investigates two aspects of branded housing projects to discuss the shared roles of political society and civil society: firstly, the role of state institutions in the production of branded housing projects as emerging spatial territories by focusing on TOKI and Emlak Konut GYO; and secondly, the role of the mass media in the production of branded housing projects as emerging spatial territories by focusing on news articles.

\section{Methodology}

Through applying the proposed Gramscian-Lefebvrian framework, a twofold methodology was undertaken for investigating the production of branded housing projects as territories. In the first phase, neoliberal restructuring in Turkey in relation to urban development is briefly discussed alongside the transformation of TOKI and 
Emlak Konut GYO into public developers. This phase unfolds the role of political society in the production process.

For the second phase of this investigation, the research applied critical discourse analysis to 181 news articles on six branded housing projects (Ağaoğlu My World Atasehir, Avrupa Konutları Atakent 3, Bizim Evler 4, Ispartakule Project, Kent Plus Ataşehir, Soyak Evostar) published between 2003-2014, and obtained via a review of the online databases of the four most highly circulated newspapers (Sabah, Hürriyet, Posta, and Zaman); and on 28 Emlak Konut GYO projects accessed through the French Institute for Anatolian Studies (IFEA) newspaper archive in order to widen the sample.

According to Machin and Mayr (2012: 5), critical discourse analysis exposes "strategies that appear normal or neutral on the surface but which may in fact be ideological and seek to shape the representation of events and persons for particular ends". Fairclough (2001: 123) argues that critical discourse analysis is an "analysis of the dialectical relationships between semiosis (including language) and other elements of social practices". Therefore, undertaking a critical discourse analysis of the news articles requires linking this content with "other elements of social practices". In this case, these dialectical relationships are discussed in terms of the relationship between the role of political society and civil society.

Fairclough (2001: 122) also stresses that semiosis "includes all forms of meaning making - visual images, body language, as well as language”. Wodok (2001: 8) also points out the importance of including non-verbal media (e.g. images) in discourse analysis that "[r]ecognition of the contribution of all the aspects of the communicative context to text meaning, as well as a growing awareness in media studies generally of the importance of non-verbal aspects of texts, has turned attention to semiotic devices in discourse rather than the linguistic ones". Following this perspective, this investigation undertook a multi-modal analysis by expanding the analysis content to images used in the news articles in addition to the textual content.

In critical discourse analysis, usually only a small number of texts are focused on (Machin and Mayr 2012: 207). However, this research aims to cover a representative sample of news articles. Machin and Mayr (Ibid.: 216) also highlight recent attempts at combining critical discourse analysis and corpus linguistics to accommodate a larger sample size. Therefore, this investigation combined quantitative and qualitative content analysis tools, which are word frequency listings and qualitative coding.

Krippendorff (2003: xvii) argues that "content analysis is an empirically grounded method, exploratory in process, and predictive or inferential in intent". Holsti (1969: 14) defines content analysis as "any technique for making inferences by objectively and systematically identifying specified characteristics of messages" (Stemler 2001). Another early definition of content analysis is that offered by Berelson (1952: 18 quoted in Krippendorff 2003: 19) as "a research technique for the objective, systematic and quantitative description of the manifest content of communication" (Krippendorff 2003: 19). While Krippendorff agrees with Berelson that content analysis is objective and systematic, he disagrees that content analysis is only quantitative, which grounds the methodological approach of this investigation in content analysis. Initially, the lexical density of the news articles was analysed by identifying the most frequently occurring words. The most frequent concepts in the news content were then identified through the lexical density and a review of the news texts by the researcher. 
Lastly, the accompanying visuals to the news articles were analysed according to their presentation and content. NVivo software was used as the analysis tool.

\section{Production of Branded Housing Projects as Territories}

\section{Political Society's Role in the Production of Branded Housing Projects}

Post-2001 reforms in legal and regulatory framework in Turkey align with the "postWashington consensus-based attempts aiming at the creation and protection of the institutions supporting market-based allocation of resources" (Özdemir 2012: 44). During this period, the legal and regulatory framework was restructured to support and encourage the expansion of construction (Balaban 2013: 63) and to restructure the real estate market (Kuyucu and Ünsal 2010: 1484). Governance, planning and urban development legislation was restructured with the aim of liberalising and deregulating planning and development regulations to enable and speed-up investment in construction, real estate, and tourism (Balaban 2013: 64). Balaban (2012) found that in Turkey, 78 laws and 10 by-laws, which were either related to the built environment or to urban planning and development controls, were completely or partially changed or enacted between the years 2002 and 2007.

31 The public sector has played a core role in the construction boom in Turkey (Balaban 2012). The state entered the real estate market through institutions such as TOKI and Emlak Konut GYO. Since 2002, TOKI has produced 698,832 housing units, located across all 81 provinces and in 800 districts in Turkey (TOKI 2016b).

The foundation of TOKI goes back to the 1980s, and was a milestone for urban development and housing in Turkey. TOKI was founded with the main responsibility of providing credit for housing production (Buğra and Savaşkan 2014: 85). Between 1984 and 2002, TOKI provided credit for the construction of 940,000 houses (Pérouse 2013: 83). In addition, between 1984 and 2003, TOKI constructed 43145 houses (including 7852 houses built by Emlak Konut GYO) (Ibid.). In practice, the state entered housing production directly as an actor by predominantly providing the funding for cooperatives and mass housing production, although this only constituted a small ratio of the housing stock.

In the post-2001 period, TOKI became an actor in the construction sector rather than remaining primarily a funding body for housing projects and developers (Balaban 2013: 64). In accordance with its new role, TOKI was restructured through a series of enacted regulations and amendments to existing legislation. In being given a new remit, TOKI became a public development company whose responsibilities and capacity went beyond housing production. In 2004, with the Government's Emergency Action Plan, public land ( 64.5 million $\mathrm{m}^{2}$ ) belonging to the Urban Land Office was transferred to TOKI (TOKI 2015). With this change, TOKI became one of the biggest land owners in Turkey (Pérouse 2013: 84). Via this new practice, TOKI has played a crucial role in introducing urban land into the real estate market (Ibid.: 83).

Emlak Konut GYO is the second public institution that has been thoroughly restructured and has contributed to the development of branded housing projects. In 2001, the banking and holding savings remits of Emlak Bank were abolished (Ibid.), and the banking activities of the institution were subsequently transferred to two other public banks (Ziraat Bankası and Halkbank), while its assets and real estate was 
transferred to TOKI (TOKI 2015). Through this transformation, Emlak Konut became a TOKI enterprise with $49.34 \%$ of the total shares belonging to TOKI, and $50.66 \%$ of the shares are open to the public (Emlak Konut GYO 2015a). Emlak Konut GYO became one of the biggest real estate investment partnerships in Turkey (Pérouse 2013: 92) valued at $\$ 2.200$ billion by 2015 (Emlak Konut GYO 2016). The total value of tenders since 2003 reached $\$ 17.78$ billion (Emlak Konut GYO 2015c), and Emlak Konut's share in total revenue generated through its revenue sharing projects totalled $\$ 4.6$ billion by September 2015 (Emlak Konut GYO 2015b). Pérouse (2013: 84) asserts that Emlak Konut GYO has become the most functional enterprise of TOKI through its restructuring.

A revenue sharing model was applied to develop profit-oriented projects. TOKI has 43 active revenue-sharing projects, including branded housing projects like Spradon, Divan Residence, and Olimpiakent (TOKI 2016a), while by 2014 Emlak Konut GYO had developed 43 branded housing projects in Istanbul alone. This partnership model is based on sharing profits from developed projects (in this case, branded housing projects) among private and public developers. While the public developer provides the land - public land - for the projects, the private developer develops and realises the projects. At the end, these two actors share the profits generated from the projects (See Figure 1).

Emlak Konut GYO defines this model as a way of ensuring "high profitability and fund flows" (Emlak Konut GYO 2015b). According to the institution, it is the "most important model in terms of generating income" (Emlak Konut GYO 2015b).

Figure1

\begin{tabular}{l|l|}
\hline Sourcing of land & \multicolumn{1}{c}{ Revenue Sharing Model ("RSM") } \\
\hline Tender process & $\begin{array}{l}\text { Within the tender process held under the internal } \\
\text { regulations of Emlak, the contractor proposes a } \\
\text { revenue share ratio together with an estimate of the } \\
\text { total revenues the project will generate. The highest } \\
\text { bidder is awarded the project }\end{array}$ \\
\hline Contractor obligations & \begin{tabular}{l} 
Whole process (financing to sale) \\
\hline Financing
\end{tabular} \\
\hline Emlak's obligations & Land, approval of design and technical control \\
\hline Risk allocation & Mainly the contractor \\
\hline Sales & Contractor and Emlak Konut \\
\hline Revenues & $\begin{array}{l}\text { Shared with contractor, minimum guaranteed to Emlak } \\
\text { Konut }\end{array}$ \\
\hline
\end{tabular}

Summary of revenue sharing model

Emlak Konut GYO 2015c

37 Through this practice, the state contributes to the production of branded housing projects as urban territories in cities in Turkey in two ways: firstly, through the 
application of neoliberal policies and transforming the legal and regulatory framework in accordance with these policies; and secondly, by entering the housing market directly to produce these branded territories.

\section{Civil Society's Role in the Production of Branded Housing Projects}

big, are identified among the most frequent words. By using this content, the projects are defined as places which are distinct from other projects or the rest of the urban pattern. In relation to being described as distinctive places, superlatives are used concurrently. Different from English grammar, to make an adjective superlative in Turkish, the word en is added before the adjective. To illustrate, to say 'the biggest' or 'the most important', en as a separate word would be added before the word 'big' or 'important'. Therefore, as a result of the concurrent use of superlatives, such as 'the biggest' or 'the most profitable', the word en meaning 'the most' was the seventh most frequent word in the news content. Through the concurrent use of superlatives, the discourse frames projects as superior or at least as distinctive places. news content as a starting point for qualitative content analysis. Then, the key concepts were identified by reviewing the news articles. Although subsampling is a method designed to create inductive codes (see Boyatzis 1998), in this research thematic codes were created by reviewing all the sample articles. These key concepts

European Journal of Turkish Studies, 23 | 2016 
were also used to run queries to identify related content, in addition to running word frequency queries. As a result, thematic codes were created and the news articles were reviewed according to these codes. According to the analysis, concurrent themes regarding the production of branded housing as territories were identified through the news articles, including projects as branded territories, projects as superior territories, and projects as territories of opportunities and advantages, which will be discussed in further detail in the following section.

Figure 2

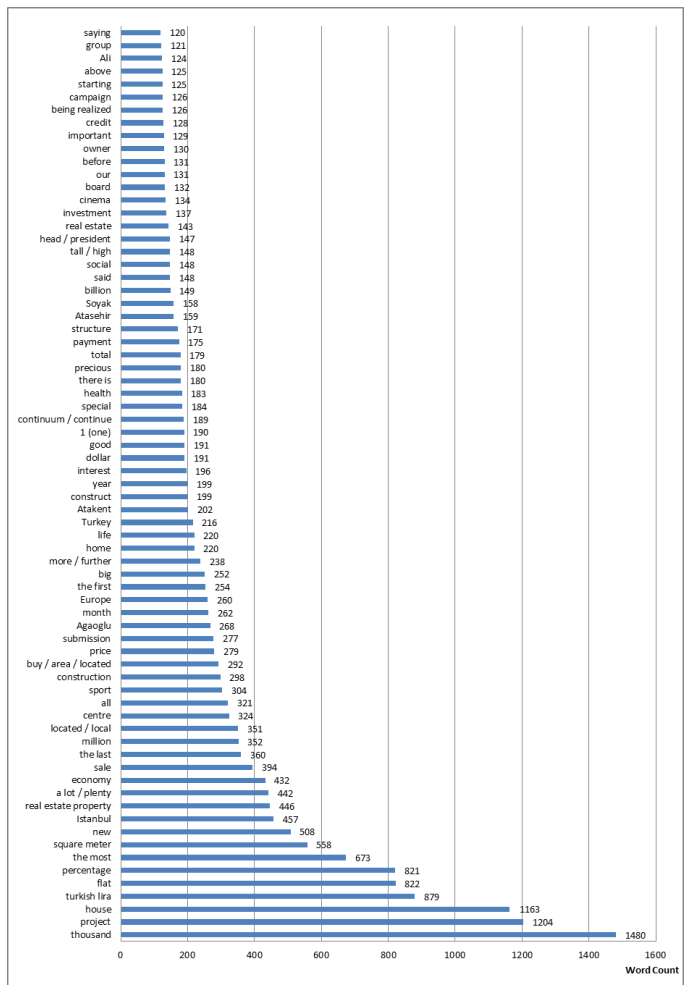

Lexical Analysis of the News Text

\section{Branded Territories}

Being branded is presented as positive throughout the news content. This framing manifests itself in both explicit and latent ways. Being branded is presented as a way of guaranteeing a certain level of quality standards which can be seen in all branded housing projects belonging to that particular brand. In this sense, having similar qualities to other projects of the same brand becomes a positive input for the appreciation of the project. This attempt to form a discursive definition contributes to the discursive formation of branded housing projects as territories.

Secondly, branded housing projects are framed as places offering more than just housing to their residents. Companies place an emphasis on the fact that the product (or the commodity) they sell is not a housing unit, but a living area. In such an approach, the developer presents the living area itself as a commodity, and proudly states that the real product being sold is the living area, not the housing unit. This 
conceptualisation supports the discursive formation of branded housing projects as territories.

\section{Superior Territories}

Projects are presented as superior living places or territories by defining them with superlatives. This usage of extremity and affirmation fosters a discourse glorifying the projects. The projects may be presented as the biggest or the most important places with their different aspects. While in some cases these definitions are latent, as in the example "We see My World as the most important project of Europe" 2 (Dünya 01/16/2008), in other cases the claim is supported with quantities as in this excerpt: "In the project, there is the biggest $-25.000 \mathrm{~m}^{2}$ - sports centre of Europe" (Yoldaş 06/19/2010). This content contributes to the discursive formation of branded housing projects as superior places to the rest of the housing stock. This idea of superiority also supports the discursive formation of the branded housing projects as territories by differentiating them from their surrounding environments.

\section{Territories of Opportunities and Advantages}

Branded housing projects are framed as territories of opportunity throughout the news content. Four types of opportunities and advantages are emphasized: gaining - projects as beneficial entities for many parties-, investment opportunities, home ownership, and services and facilities.

First, the branded housing projects are framed as beneficial developments that serve several parties, including house buyers, homeowners, residents, people, the public, surrounding districts, the country and the economy. In other words, according to this discourse, building such projects is a win-win situation.

Firstly, in the texts the projects are framed as territories of opportunity for the target audience. The target audience is addressed as buyers, consumers, clients, citizens, homeowners, residents, renters, and aspiring homeowners. The message is that living in these projects will contribute to the quality of life of the residents.

What is this plus concept? It means creating things that will add value in people's life. $^{3}$ (Sabah 11/27/2005)

Ağaoğlu, who states that houses built in the previous period are not habitable considering the materials used, said that

now we are creating a chance to have quality houses with accessible and affordable prices. ${ }^{4}$ (Dünya 01/16/2008)

Secondly, it is presented in the text that the public sector will benefit from these projects by building partnerships with the development companies and receiving a share of the revenues. This discourse frames the projects as a means for the public sector to gain otherwise unobtainable profits from development.

Ağaoğlu Group Chairman Ali Ağaoğlu, who will transfer to the state 400 million dollars... said that the revenue from this project will be 1 billion dollar; 400 million dollar of this will be transferred to the state. "The State gets an unbelievable profit from land which it may not sell for even 100 million without doing anything. With the profit it gained from here, it provides services which private initiative aims to provide but cannot accomplish. ${ }^{5}$ (Cumhuriyet 04/03/2006) 
Thirdly, the projects are framed as territories which will add value to the surrounding environment, to the districts where they are located, and to the city itself. In this representation of the projects, the branded housing projects are framed as distinctive territories distinguishable from their surroundings.

CEO of Artaş Construction Süleyman Çetinsaya said that together with TOKI and Emlak GYO, they played a role in appreciation of the district with the houses which they have built in Halkali. ${ }^{6}$ (Sabah 06/17/2012)

5 Second, the projects are framed as places offering investment opportunities. In the text, projects are framed as producing profits and thus as good investment opportunities for the target audience. The notion of the projects as a means of investment is emphasized throughout the news content. This notion is supported in the text by framing housing as the most convenient and traditional investment tool for individuals. Part of this discourse is the profitability of the projects.

Ali Ağaoğlu, who emphasized the fact that buying a house is the smartest investment, said that

The ones who buy houses always win. ... ${ }^{7}$ (Sabah 01/20/2010)

Third, home ownership is a core content in the news articles. In the news content, the term 'home owners' [ev sahibi] is used interchangeably with 'house owners', 'flat owners' and 'deed owners's. In addition, the targeted audience is named as investors, consumers, customers, people who would like to be home/flat/house owners. The definitions connote both the economic and social aspects of homeownership.

Being a renter is framed as something negative, and even something to be saved / rescued from, while on the contrary, becoming a home owner is framed as a desired situation, a goal to be achieved.

Projects in this respect are framed as developments which create chances or opportunities to become home owners, as in this example:

It creates inescapable opportunities for the ones who would like to be homeowners. ${ }^{9}$ (Çelebi 05/11/2009)

Fourth, the projects are presented as whole packages of commodities, including housing, social services and facilities. In the news articles, services and facilities provided within the confines of the projects are presented by listing them as part of the news content. In this sense, the projects are defined as territories offering listed services and facilities to their residents. This framing contributes to the discursive production of the branded housing projects as territories of opportunities. It is a strong stance throughout the news context, a definitive approach for this territorial production.

Cetinsaya said that a city square, a 45-thousand-square metre grove, a four-star hotel, 15 shops, pharmacy, café and restaurants will be situated in the project. In the grove, there will be common areas such as swimming pools, and walking and running tracts. In Atakent 3, there are a big pool, waterfalls between housing blocks and pools as well. ${ }^{10}$ (Yoldaş 02/01/2011)

Framing branded housing projects as territories of opportunities and advantages contributes to the discursive formation of these places as territories through the promises made to future residents. These contents (e.g. a place for investment, a beneficial place, places offering various services) foster the differentiation of these projects as particular territories discursively. 


\section{Accompanying Visuals of the News Articles}

The accompanying visuals to the news articles were analysed as part of a multi-modal discourse analysis undertaken for the investigation of branded housing projects as territories. The visual content was briefly analysed through their presentation and content. While the presentation of the images was analysed through the mode of representation of the building, project or district, and colours, the content of the images were analysed through focusing on the spatial aspects and the representation of people in the visuals.

According to the findings, in more than two thirds of the visuals presenting representations of the project or building, a render or model was used. This results from the fact that at the time of publication the projects were either at a preconstruction or under-construction stage. The images mostly present general views of the projects and the buildings. While the use of general views of the projects demonstrates a focus on the project itself (rather than the surrounding district or neighbourhood), the use of building exteriors provides a general overview of the building from the outside without focusing on the housing unit itself.

8 People represented in the visuals mostly include the CEOs of development companies and public officials. Gender-based analysis shows that women are only included in 24 visuals, while men are comparably represented in 71 of the accompanying visuals. Considering the gender inequalities among executives in Turkey - the total ratio of female directors in companies comprises only $12.2 \%$ (ILO 2015) - these results are not surprising. In terms of the type of clothing worn in the visuals, in 53 visuals people are dressed in suits, whereas in only 24 visuals people are more casually attired. In many cases, the news was collected either from attending launch events and press conferences or from company and public sources.

The analysis of the images accompanying the news articles reveals that the focus of the visuals is primarily on presenting the projects in general terms without representing future or current (daily) life in the projects and thereby connoting the economics of the projects with executive men in suits.

\section{Conclusion}

According to the Lefebvrian-Gramscian conceptual framework presented in this article, the analyses of the production dynamics of branded housing projects provides insights and results supporting the notion of the production of branded housing projects as territories through political society and civil society. Firstly, regarding political society, the findings from this research show that political society occupies a powerful position for directing urban development, befitting its class position according to neoliberalization as a class project (Harvey 2005), by restructuring the legal and regulatory framework. The transformation of the legal and regulatory framework to foster neoliberal urbanization practices is one of the main dynamics behind the development of branded housing projects as a new mode of territory production in contemporary Turkey. The revenue-sharing model clearly exemplifies the position of the neoliberal state with its practices of fostering the privatisation of public land, with 
its profit-orientedness, and with its class position (e.g. housing provision by state for higher and middle income groups rather than affordable and social housing).

Secondly, regarding civil society, the findings from the critical discourse analysis can be summarised as follows: First, the projects are associated with the economy / monetary value of the houses while they are presented as individual investment and development opportunities for the public sector to collect profits, which contributes to the development of a discourse emphasizing the exchange value of these territories rather than their use value. Second, being branded is presented as a positive aspect of these projects, which strengthens the association of these territories as consumer products rather than neighbourhoods, therefore, fostering their commodity character. Third, the projects are presented as distinctive places that are superior to other urban areas, which associates them with the notion of being better places to live than 'normal' neighbourhoods. This discourse contributes to the production of consent mainly by associating these places with the superior and positive characteristics of a living area / neighbourhood. A consideration of these aspects of the media discourse offers a very clear example of the imposition of the views (of one class over another) in the creation of common sense. Fourth, the projects are framed as territories offering a range of opportunities such as increasing quality of life or improving the surrounding environment. Fifth, the projects are presented as developments providing homeownership opportunities, while idealising homeownership and framing living in a rented house in very negative terms. In this respect, the discourse fosters homeownership and, therefore, the expansion of private property. Last, the projects are framed as territories providing urban services and facilities to their residents comprehensively. In the discourse, it is presented that anything a citizen can expect as an urban infrastructure is provided in these areas privately and in good quality. Therefore, this discourse latently claims that the residents of branded housing projects do not need municipal or public services which are not as good quality as the projects' provision. Such discursive formation 'normalising' the private provision of municipal services is extremely alarming considering the common need for such services in urban spaces and their deficit in many districts in Istanbul. To illustrate, the ratio of publicly accessible green spaces (public parks and gardens) in Istanbul comprises only $1.5 \%$ of the total land area, compared with $38.4 \%$ in London, $14.4 \%$ in Berlin, and $46 \%$ in Sydney (BOP Consulting 2014). These numbers demonstrate an already alarming situation in Istanbul with branded housing projects only offering an exclusive solution to this public problem: limited-access to green spaces for those who can afford to live in branded housing projects. The production of common sense as normalising the private provision of green spaces is extremely concerning considering the future of public open spaces and the production of exclusionary spaces.

62 As a result, this analysis discusses the complementary nature of political society and civil society in the production of territories in contemporary Turkey while also arguing that the phenomenon of branded housing projects can be regarded as emerging spatial territory formation. This emergence manifests in the proliferation and expansion of these projects, and the number of housing units provided within project areas. The research argues that the development of branded housing projects is part of a wider process of restructuring in Turkey, neoliberalization, which has been ongoing for the last forty years. Political society plays a core role in this restructuring by providing the legal and regulatory framework and by transforming it into a neoliberal state. The 
research also argues that such an extensive production of branded housing projects is not likely to be realized without considerable social consent. The aforementioned results of the discourse analysis of news articles shed light on the dynamics of this social consent production while explaining the dynamics of the production of branded housing projects as emerging territories. The case of branded housing projects as emerging territories demonstrates how a new mind-set, common sense, can transform urban spaces we live in a relatively short period of time, fifteen years, and with alarming levels of creative destruction. The results also raise concerns regarding the 'normalisation' of the private provision of urban services and its effects on fostering the commodification of urban services.

\section{BIBLIOGRAPHY}

Aalbers, Manuel B (2013a). 'Debate on Neoliberalism in and after the Neoliberal Crisis', international Journal of Urban and Regional Research 37 (3), p. 1053-1057. DOI:

10.1111/1468-2427.12061.

Aalbers, Manuel B (2013b). 'Neoliberalism Is Dead ... Long Live Neoliberalism!' International Journal of Urban and Regional Research 37 (3), p. 1083-1090. DOI: 10.1111/1468-2427.12065.

Altun, Didem Akyol (2012). ‘İzmir'de Yeni Bir Konut Üretim Süreci Olarak Kapalı Konut Siteleri’, Ideal Kent 6, p. 40-61.

Ataay, Faruk (2006). 'Kamu Yönetimi Reformu ve Demokratikleşme Sorunu', in Ataay, Faruk (2006) Neoliberalizm ve Devletin Yeniden Yapılandırılması, Ankara, Deki. URL: https:// www.academia.edu/2317588/Neoliberalizm_Kamu_Reformu_ve_Demokrasi.

Bagaeen, Samer (2010). 'Gated Urban Life versus Kinship and Social Solidarity in the Middle East', in Bagaeen, Samer; and Uduku, Ola (eds.) Gated Communities: Social Sustainability in Contemporary and Historical Gated Developments, London-New York, Routledge, p.15-26.

Balaban, Osman (2012). 'The Negative Effects of Construction Boom on Urban Planning and Environment in Turkey: Unraveling the Role of the Public Sector', Habitat International 36 (1), p. 26-35. DOI: 10.1016/j.habitatint.2011.05.003.

Balaban, Osman (2013). ‘Neoliberal Yeniden Yapılanmanın Türkiye Kentleşmesine Bir Diğer Armağanı: Kentsel Dönüşümde Güncelin Gerisinde Kalmak’, in Çavdar, Ayse; Tan, Pelin (eds.) İstanbul: Müstesna şehrin İstisna Hali, Istanbul, Sel, p. 51-80.

Bayırbağ, Mustafa Kemal (2010). 'Devletin Yeniden Ölçeklenmesi, Dışlanma ve Neoliberalizmin Zamansallığı', in Sen, Beşime; Doğan, Ali Ekber (eds.) Tarih, sinıflar ve kent, Ankara, Dipnot, p. 271-308.

Blakely, Edward James; Snyder, Mary Gail (1997). Fortress America: Gated Communities in the United States, Washington DC, Brookings Institution Press.

Bodnar, Judit; Molnar, Virag (2010). 'Reconfiguring Private and Public: State, Capital and New Housing Developments in Berlin and Budapest', Urban Studies 47 (4), p. 789-812. DOI:

10.1177/0042098009351188. 
BOP Consulting (2014). 'World Cities Culture Report 2014', Greater London Authority. URL: http://www.worldcitiescultureforum.com/assets/others/

World_Cities_Culture_Report_2014_hires.pdf

Borsdorf, Axel; Hidalgo, Rodrigo (2010). 'From Polarization to Fragmentation. Recent Changes in Latin American Urbanization', in Lindert, Paul; Verkoren, Otto (eds.) Decentralized Development in Latin America: Experiences in Local Governance and Local Development, Dordrecht, Springer Science \& Business Media, p. 23-34. DOI: 10.1007/978-90-481-3739-8_2.

Boyatzis, Richard (1998). Transforming Qualitative Information: Thematic Analysis and Code Development. Thousand Oaks, CA, SAGE Publications.

Brenner, Neil, Theodore, Nik (2002). 'Cities and the Geographies of "Actually Existing Neoliberalism”, Antipode 34 (3), p. 349-79. DOI: 10.1111/1467-8330.00246.

Buğra, Ayşe; Savaşkan, Osman (2014). New Capitalism in Turkey: The Relationship Between Politics, Religion and Business, Cheltenham, UK, Edward Elgar Pub.

Candan, Ayfer Bartu; Kolluoğlu, Biray (2008). ‘Emerging Spaces of Neoliberalism: A Gated Town and a Public Housing Project in Istanbul', New Perspectives on Turkey, 39, p. 5-49. DOI: 10.1017/ S0896634600005057.

Çelebi, Erkan (May 11, 2009). 'Konutta Bahar firsatları', Hurriyet. URL: http:// www.hurriyet.com.tr/konutta-bahar-firsatlari-11591701.

Cox, Kevin (2002). Political Geography: Territory, State and Society, Malden, MA, Wiley. DOI: 10.1002/9780470693629.

Cumhuriyet (April 3, 2006). 'Yapı ve Turizmde İddialıyı', Cumhuriyet. URL: http:// www.yapi.com.tr/haberler/yapi-ve-turizmde-iddialiyiz_42564.html.

Debord, Guy (1994). The Society of the Spectacle, New York, Zone Books.

Delaney, David (2008). Territory: A Short Introduction, Malden, MA, John Wiley \& Sons.

Demirtas, Birgül (2012). ‘Turkish Foreign Policy Under The AKP Governments: An Interplay of Imperial Legacy, Neoliberal Interests and Pragmatism', in Simten, Coşar; Yücesan-Özdemir, Gamze (eds.) Silent Violence: Neoliberalism, Islamist Politics and the AKP Years in Turkey, Ottawa, Red Quill Books, p. 213-250.

Dünya (Jan. 16, 2008). ‘Ağaoğlundan Luks Konuta Sıfır Faizli Kredi’, Dünya.

Elden, Stuart (2004). Understanding Henry Lefebvre, London-New York, Continuum.

Emlak Konut GYO (2015a). 'Emlak Konut GYO Partnership Structure', Emlak Konut GYO Partnership Structure. http://www.emlakkonut.com.tr/Page/236/partnership_structure.html.

Emlak Konut GYO (2015b). 'Emlak Konut GYO A.ş. Activity Report', Emlak Konut GYO, http:// www.emlakkonut.com.tr/_Assets/Upload/Images/file/FaaliyetRaporlari/ENG-

EKGYO_2015_Q3\%20V2_Tum_Ekler.pdf.

Emlak Konut GYO (2015c). 'Emlak Konut GYO Yatırımcı Sunumu', December 25, http:// www.emlakkonut.com.tr/_Assets/Upload/Images/file/YatirimciSunumu/Turkce-Y-13.11.15.pdf. Emlak Konut GYO (2016). 'Yatırımcı İlişkileri', Emlak Konut GYO Investor Relations. http:// www.emlakgyo.com.tr/yatirimci/default.aspx.

Fairclough, Norman (2001). 'Critical discourse analysis as a method in social scientific research', in Wodak, Ruth; Meyer, Michael (eds.), Methods of Critical Discourse Analysis. Thousand Oaks, CA, SAGE Publications, p. 162-186. 
Forgacs, David (2000). The Antonio Gramsci Reader: Selected Writings 1916-1935, New York, New York University Press.

Geniş, şerife (2007). 'Producing Elite Localities: The Rise of Gated Communities in Istanbul', Urban Studies 44 (4) p. 771-798. DOI: 10.1080/00420980601185684.

Güngen, Ali Rıza (2006). ‘1980’ler Türkiye’sinde Devlerin Yeniden Yapılandırılmasına Dair Yaklaşımlar Üzerine Eleştirel Notlar’, in Türkiye’de Kapitalizmin Gelişimi, Ankara, Dipnot, p. 331-354.

Hansson, Mats G. (2007). The Private Sphere: An Emotional Territory and Its Agent, Dordrecht, Springer Science \& Business Media.

Harvey, David (2005). Spaces of Neoliberalization: Towards a Theory of Uneven Geographical Development, Stuttgart, Franz Steiner.

Harvey, David (2007). A Brief History of Neoliberalism, Oxford, Oxford University Press.

ILO [International Labour Organization] (2015). 'Women in Business and Management', Geneva, international Labour Office. http://www.ilo.org/wcmsp5/groups/public/---dgreports/--dcomm/---publ/documents/publication/wcms_316450.pdf.

Jones, Steve (2006). Antonio Gramsci, London-New York, Routledge.

Keyman, E. Fuat; Gümüş̧̧ü, şebnem (2014). Democracy, Identity and Foreign Policy in Turkey: Hegemony Through Transformation, London-New York, Palgrave Macmillan. DOI: 10.1057/978113727712.

Kipfer, Stefan (2002). 'Urbanization, Everyday Life and the Survival of Capitalism: Lefebvre, Gramsci and the Problematic of Hegemony’, Capitalism Nature Socialism 13 (2), p. 117-149.

Krippendorff, Klaus (2003). Content Analysis: An Introduction to Its Methodology, Thousand Oaks, CA, SAGE.

Kurtuluş, Hatice (2005). ‘İstanbul'da Kapalı Yerleşmeler: Beykoz Konakları Örneğı', in Kurtuluş, Hatice (ed.), İstanbul'da Kentsel Ayrışma. Mekansal Dönüşümde Farklı Boyutlar, Istanbul, Bağlam, p. 161-186.

Kuyucu, Tuna; Ünsal, Özlem (2010). “'Urban Transformation” as State-Led Property Transfer: An Analysis of Two Cases of Urban Renewal in Istanbul', Urban Studies 47 (7), p. 1479-1499. DOI: 10.1177/0042098009353629.

Lefebvre, Henri (1992). The Production of Space, Malden, MA, Wiley.

Lofland, Lyn H (1998). The Public Realm: Exploring the City's Quintessential Social Territory, Transaction Publishers.

Machin, David; Mayr, Andrea (2012). How to Do Critical Discourse Analysis: A Multimodal Introduction. Thousand Oaks, CA, SAGE Publications.

Moore, Margaret (2015). A Political Theory of Territory, Oxford, Oxford University Press.

Mosco, Vincent (2009). The Political Economy of Communication, Thousand Oaks, CA, SAGE Publications.

Özdemir, Ali Murat (2012). 'Fragments of Changes in the Legal System in the AKP Years: The Development and Reproduction of a Market Friendly Law', in Simten, Coşar; Yücesan-Özdemir, Gamze (eds.) Silent Violence: Neoliberalism, Islamist Politics and the AKP Years in Turkey, Ottawa, Red Quill Books, p.43-66. 
Peck, Jamie; Theodore, Nik; Brenner, Neil (2009). 'Neoliberal Urbanism: Models, Moments, Mutations', SAIS Review 29 (1), p. 49-66. URL: http://www.sociology.as.nyu.edu/docs/IO/222/ Peck.Theodore.Brenner.2009.pdf.

Peck, Jamie; Theodore, Nik; Brenner, Neil (2013). ‘Neoliberal Urbanism Redux?' International Journal of Urban and Regional Research 37 (3), p. 1091-1099. DOI : 10.1111/1468-2427.12066.

Pérouse, Jean-François (2013). 'Kentsel Dönüşüm Uygulamalarında Belirleyici Bir Rol Üstlenen Toplu Konut İdaresi'nin (TOKI) Belirsiz Kimliği Üzerine Birkaç Saptama', in Çavdar, Ayşe; Tan, Pelin (eds.) İstanbul: Müstesna Şehrin İstisna Hali, İstanbul, Sel, p. 81-96.

Pow, Choon-Piew (2009). 'Public Intervention, Private Aspiration: Gated Communities and the Condominisation of Housing Landscapes in Singapore', Asia Pacific Viewpoint 50 (2), p. 215-227. DOI : 10.1111/j.1467-8373.2009.01394.x.

Sabah (Nov. 27, 2005). 'Kadınları Bu Mutfaklar Tavladı', Sabah. URL : http://arsiv.sabah.com.tr/ 2005/11/27/eko113.html.

Sabah (Jan. 20, 2010). 'Ağaoğlu Üç Projede Tapu Dağıttı «10 Bin Yeni Konut Yolda Dedi»', Sabah. URL : http://www.mimdap.org/?p=31197.

Sabah (June 17, 2012). 'Atakent 3 Sahibine \% 66 Kazandırdı', Sabah. URL: http:// www.sabah.com.tr/ekonomi/2012/06/17/atakent-3-sahibine--66-kazandirdi.

Sarıçayır, Ecem (Jan 21, 2014). 'İstanbul'da markalı konut sayısı 400 bine ulaştı', Arkitera. URL: http://www.arkitera.com/haber/19381/istanbulda-markali-konut-sayisi-400-bine-ulasti.

Stemler, Steve (2001). 'An overview of content analysis', Pract. Assess. Res. Eval. 7(17). URL: http:// pareonline.net/getvn.asp?v=7\&n=17.

Thomas, Peter D. (2011). The Gramscian Moment: Philosophy, Hegemony and Marxism, Chicago, Ill, Historical Materialism.

TOKI (2015). ‘Background', TOKI. URL : http://www.toki.gov.tr/en/background.html.

TOKI (2016a). 'TOKI Revenue-Sharing Projects', TOKI. URL : http://www.toki.gov.tr/proje-tipinegore-uygulamalar.

TOKI (2016b). ‘TOKI Activity Report', TOKİ. URL: http://www.toki.gov.tr/AppResources/ UserFiles/files/FaaliyetOzeti/ozet.pdf.

Wodak, Ruth (2001). 'What CDA is about - a summary of its history, important concepts and its developments', in Wodak, Ruth; Meyer, Michael (eds.), Methods of Critical Discourse Analysis. Thousand Oaks, CA, SAGE Publications, p.1-33.

Yoldaş, Bülent (June 19, 2010). ‘Brad Pitt Gibi Fit Olurum', Sabah. URL : http:// www.emlaktasondakika.com/haber/sektorden-haberler/brad-pitt-gibi-fit-olurum/2385.

Yoldaş, Bülent (Feb. 1, 2011). '2011'in İlk Konut Projesi Avrupa Konutlarından Atakent 3', Sabah. http://www.sabah.com.tr/ekonomi/ 2011/01/02/2011in_ilk_konut_projesi_avrupa_konutlarindan_atakent_3.

Zabc1, Filiz (2012). 'Internationalisation of Dependency: The AKP's Dance with the Global Institutions of Neoliberalism', in Simten, Coşar; Yücesan-Özdemir, Gamze (eds.) Silent Violence: Neoliberalism, Islamist Politics and the AKP Years in Turkey, Ottawa, Red Quill Books, p.251-268. 


\section{NOTES}

1. In Turkish: bin, proje, konut, Turk lirast, daire, yüzde, en (respectively).

2. In Turkish: "My World'u Avrupa'nın en önemli projelerinden biri olarak görüyoruz" (Dünya 2008).

3. Evet aynı konsepti uygulayacağız, 'plus' konsepti. Nedir bu plus konsepti? İnsanların yaşamına değer katacak şeyler yaratmak demek. Yani malzemeden, inşaat tekniğine kadar, A grubunun kullandığı her şeyi kullanıp, B grubunun satın alabileceği fiyata evler yaratmak.

4. İstanbul'da geçmiş dönemde yapılan konutların kullanılan malzeme dikkate alınınca yüzde 70'inin oturulabilecek durumda olmadığını belirten Ağaoğlu, "şimdi biz ulaşılabilir ve ödenebilir fiyatlarla nitelikli konut sahip olma şansı yaratıyoruz" dedi. .

5. Devlete 400 milyon dolar aktaracak Ağaoğlu Grubu Başkanı Ali Ağaoğlu [...] Ağaoğlu, bu projeden elde edilecek satış hasilatının yaklaşık 1 milyar dolar cıvarında olacagını, bunun 400 milyon dolarının devlete aktarılacağını Ağaoğlu, "DevIet, belki de 100 milyon dolara satamayacağı bir yeri, elini sıcak sudan soğuk suya sokmadan, inanılmaz kar elde ediyor. Buradan elde ettiği kaynakla özel teşşebbüsün hedefleyip de yapamadığı hizmeti yapmış oldu.".

6. Artaş İnşaat Yönetim Kurulu Başkanı Süleyman Çetinsaya, TOKI ve Emlak Konut GYO ile birlikte Halkalı'da inşa ettikleri konutlarla bölgenin değer kazanmasında da rol oynadıklarını söyledi. .

7. Konut satın almanın en akıllıca yatırım olduğunu vurgulayan Ali Ağaoğlu; "Konut alanlar daima kazanir. ..."(Sabah 01/20/2010).

8. In Turkish: konut sahibi, daire sahibi, tapu sahibi (respectively).

9. konut sahibi olmak isteyenler için kaçırılmayacak firsatlar yaratıyor. (Konutta bahar firsatları).

10. Çetinsaya, proje içinde bir kent meydanı, 45 bin metrekarelik bir koru, 4 yıldızl bir otel, 15 mağaza, eczane, cafe ve restoranların yer alacağını anlattı. Koru içinde yüzme havuzları, yürüyüş ve koşu parkurları gibi ortak alanlar yer alacak. Atakent 3'te büyük bir gölet, konut bloklarının arasında şelaleler ve havuzlar da bulunuyor. Çetinsaya, projede bir kent meydanı oluşturularak, buraya memleketi Kayseri'nin kent meydanındaki tarihi saat kulesinin bir benzerinin de inşa edileceğini açıkladı.

\section{ABSTRACTS}

Cities in Turkey, following the neoliberal restructuring of the country, have undergone a process of transformation in the last decade at a greater pace than experienced in previous periods. Through these processes, while new territories have been constructed, previous formations have been dismantled. While some of these constructed territories are abstract (e.g. Nomenclature of Units for Territorial Statistics [NUTS] regions), some are tangible and physically defined such as branded housing enclaves.

Branded housing projects produce territories in the form of housing enclaves, which provide key services and facilities within their confines exclusively for project residents. By 2013, the number of branded housing projects located in Istanbul alone numbered 852 with the number of units provided by these projects amounting to $7.7 \%$ of the total housing stock the city (Sarıçayır 01/21/2014). This paper argues that these territories are co-produced by political society and civil society (in Gramscian terms): while political society regulates and directly contributes to the production of these territories through public actors involved in the branded housing projects, civil society contributes through the production of social consent for such developments. 
The article discusses the role of political society and civil society in the production of branded housing projects by focusing on the case of Emlak Konut GYO (Real Estate Partnership) projects developed in Istanbul between 2003 and 2014. Firstly, the role of political society is discussed through the roles of TOKI (Housing Development Administration of Turkey) and Emlak Konut GYO as major public actors in the development of these territories; and secondly, the role of civil society is discussed through excavating the traces of production of social consent for branded housing projects in news articles published on Emlak Konut GYO projects between 2003 and 2014. The paper concludes that branded housing projects are emerging as spatial territories in contemporary Turkey as a result of hegemonic struggle through political society and civil society.

\section{INDEX}

Keywords: branded housing, neoliberal urbanization, political society, civil society, production of space

\section{AUTHOR}

\section{BILGE SERIN}

Heriot-Watt University

bs165@hw.ac.uk 